\title{
Ganaxolone: A New Treatment for Neonatal Seizures
}

\author{
Tamara Yawno ${ }^{1,2 *}$, Suzie L. Miller ${ }^{1,2}$, Laura Bennet ${ }^{3}$, Flora Wong ${ }^{1,4}$, Jonathan J. Hirst ${ }^{5}$, \\ Michael Fahey ${ }^{4}$ and David W. Walker ${ }^{1,6}$
}

\begin{abstract}
${ }^{1}$ Ritchie Centre, Hudson Institute of Medical Research, Clayton, VIC, Australia, ${ }^{2}$ Department of Obstetrics and Gynaecology, Monash University, Clayton, VIC, Australia, ${ }^{3}$ Department of Physiology, The University of Auckland, Auckland, New Zealand, ${ }^{4}$ Department of Paediatrics, Monash University, Clayton, VIC, Australia, ${ }^{5}$ School of Biomedical Sciences and Pharmacy, University of Newcastle, Callaghan, NSW, Australia, ${ }^{6}$ School of Health and Biomedical Sciences, RMIT University, Bundoora, VIC, Australia
\end{abstract}

Neonatal seizures are amongst the most common neurologic conditions managed by a neonatal care service. Seizures can exacerbate existing brain injury, induce "de novo" injury, and are associated with neurodevelopmental disabilities in post-neonatal life. In this mini-review, we present evidence in support of the use of ganaxolone, a GABA ${ }^{A}$ agonist neurosteroid, as a novel neonatal therapy. We discuss evidence that ganaxolone can provide both seizure control and neuroprotection with a high safety profile when administered early following birth-related hypoxia, and show evidence that it is likely to prevent or reduce the incidence of the enduring disabilities associated with preterm birth, cerebral palsy, and epilepsy. We suggest that ganaxolone is an ideal anti-seizure treatment because it can be safely used prospectively, with minimal or no adverse effects on the neonatal brain.

OPEN ACCESS

Edited by:

Nicola Maggio,

Sackler Faculty of Medicine, Tel Aviv

University, Israe

Reviewed by:

Hongyu Sun,

Carleton University, Canada

Hermona Soreq,

Hebrew University of Jerusalem, Israel

*Correspondence:

Tamara Yawno

tamara.yawno@hudson.org.au

Received: 30 May 2017 Accepted: 02 August 2017 Published: 22 August 2017

Citation:

Yawno T, Miller SL, Bennet L, Wong F,

Hirst JJ, Fahey $M$ and Walker DW (2017) Ganaxolone: A New Treatment

for Neonatal Seizures.

Front. Cell. Neurosci. 11:246. doi: 10.3389/fncel.2017.00246
Keywords: neurosteroids, ganaxolone, phenobarbitone, neonatal seizures, hypoxic-ischemic encephalopathy, neuroprotection

\section{NEONATAL SEIZURES}

Seizures in neonates are relatively common; in fact, this is the stage of life they are most likely to occur (Khanna et al., 2013). Their presence is often the first sign of significant brain dysfunction. Although often of short duration, they are nevertheless powerful predictors of long-term cognitive and developmental impairment (Glass, 2014). Neonatal seizures are associated with cognitive, intellectual, behavioral, and sensorimotor deficits (Glass, 2014) independent of any other associated brain damage. Thus, there is a great need to find an effective anti-seizure therapy.

Identification of seizure in neonates is often hard, and treatment decisions remain problematic. It is uncertain whether it is better to treat electrographic or clinical seizures associated with cerebral hypoxia-ischaemia (Bjorkman et al., 2010). Despite more than $60 \%$ of neonatal seizures being solely electrographic, without obvious physical manifestations, most management focuses on clinical seizures (Bye and Flanagan, 1995). However, the increased use of brain activity monitoring through a continuous recording of the electroencephalogram (EEG) has revealed that the actual rate of neonatal seizures is at least double the number reported by clinical observation alone (Glass, 2014). With the increasing use of bedside monitors to continuously record EEG in neonatal intensive care units, we have transitioned from a reliance on clinical seizure events (fits/jerks/abnormal body movements) to a more comprehensive approach that includes EEG identification of electrographic seizures and subtle/subclinical seizures (Glass, 2014). 
Electrographic seizures are highly correlated with neurological compromise (McBride et al., 2000). Almost half of term infants with seizures are at risk of developing cerebral palsy, cognitive deficits, and epilepsy (Glass and Wirrell, 2009). In human infants, even a brief period of seizures is associated with altered brain development, long-term structural changes, increased seizure susceptibility, and impaired cognition (Holmes, 2009). While the neurological outcome is highly influenced by the underlying etiology of seizures, there is substantial evidence from human studies, and animal models that seizures independently induce, or worsen, brain injury (Bjorkman et al., 2010; Srinivasakumar et al., 2015). In the developing brain, seizures may increase neuronal injury by increasing metabolic demand, altering cerebral oxygenation, inducing a further release of excitatory neurotransmitters, and altering neuronal connections (Wasterlain et al., 2013).

Nonetheless, current treatment of neonatal seizures, only reduces clinical seizure events in a subset of infants, while the underlying electrographic discharges often remain unchanged (Glass, 2014). EEG assessment of neonatal seizures is considered gold-standard, and anti-seizure treatments must target a reduction in electrographic seizures. The clinical evidence is clear that reduction of the incidence and duration of electrographic seizures in neonates also reduces the severity of brain injury on MRI, and improves neurofunctional outcomes (Srinivasakumar et al., 2015).

\section{CURRENT TREATMENT OF NEONATAL SEIZURES}

Phenobarbitone was discovered as an anti-seizure medication for adults in 1912 and was progressively adopted into clinical practice for neonates, without examination of its neurodevelopmental effects. Phenobarbitone remains the first-line treatment for infants with seizures today (WHO) (World Health Organisation, 2011). The standard second-line treatment for neonatal seizures is phenytoin, another older generation drug. Phenobarbitone and phenytoin do not provide good electrographic seizure control, with $>50 \%$ of neonates still demonstrating electrographic seizures despite medication (Painter et al., 1999; Boylan et al., 2002, 2004; Rennie and Boylan, 2007).

Each of these medications has documented side effects. Phenobarbitone may cause respiratory depression and impaired myocardial function, while phenytoin is known to cause cardiac arrhythmia and hypotension (Levene, 2002). Antenatal exposure to phenobarbitone or phenytoin is linked to reduced brain volume in infancy and subsequent learning deficits (Dessens et al., 2000). Animal studies show that phenobarbitone induces cell death in gray and white matter and reduces synaptic connectivity in the developing, immature brain (Bittigau et al., 2003; Dringen, 2005; Forcelli et al., 2012). In addition, phenobarbitone is associated with significant deficits in motor ability and cognition and can increase anxiety behaviors (Brodie and Kwan, 2012; Forcelli et al., 2012). A meta-analysis in human infants found that anticonvulsant therapy following perinatal asphyxia did not significantly reduce seizure burden, and did not improve outcomes (Evans et al., 2007). A recent Cochrane review (Young et al., 2016) revealed that there is low to very low-quality evidence addressing the use of barbiturate (phenobarbitone) for the treatment of seizures in late preterm/ term infants following perinatal asphyxia. The analysis found that there was no reduction in mortality and little data addressing the longterm consequences of barbiturate use in neonates, suggesting that future studies should address clinically important reductions in mortality and their long-term neurological impairments. Ongoing questions surround the clinical efficacy and safety of phenobarbitone for the treatment of neonatal seizures, which prompts the critical need for alternative therapeutic options.

\section{Neurosteroids}

Neurosteroids derived from progesterone, such as allopregnanolone, are endogenously produced neurohormones that interact with $\mathrm{GABA}^{\mathrm{A}}$ receptors and increase CNS inhibition (Belelli and Lambert, 2005; Reddy and Rogawski, 2012). The high levels of neurosteroids in the brain before birth are due to placental production of progesterone and other precursor steroids which are rapidly converted to pregnane steroids such as allopregnanolone in fetal brain until the time of birth (Nguyen et al., 2003). Allopregnanolone, also known as $5 \alpha$-pregnan- $3 \alpha-$ ol-20-one or $3 \alpha, 5 \alpha$-tetrahydroprogesterone $(3 \alpha, 5 \alpha-\mathrm{THP})$, as well as brexanolone (Belelli and Lambert, 2005; Kanes et al., 2017), positively modulates the $\mathrm{GABA}^{\mathrm{A}}$ receptor causing a global inhibition of CNS activity. We have interrogated the neurosteroid synthetic pathway, to identify candidate agents for neuroprotection, specifically following hypoxia-ischemia. We have shown that in fetal life allopregnanolone not only promotes brain growth and protects against hypoxic damage, but it also provides a tonic suppression of brain activity, as revealed through EEG, and fetal motion and breathing movements (Nicol et al., 1999, 2001). There is a rapid loss of neurosteroidinduced inhibition of brain activity at birth after the placenta is removed, and neurosteroids such as allopregnanolone are cleared quickly from the neonate's circulation-the half-life of allopregnanolone is estimated to be $10 \mathrm{~min}$ (Johansson et al., 2002). The physiological sense of this rapid change of CNS neurochemistry is that the healthy term fetus "wakes up" once the tonic inhibition of in utero neurosteroids has is removed upon delivery. But for the post-hypoxic fetus, the loss of this physiological inhibition exposes the brain to oxidative stress and other neurochemical changes that increase excitability, and so, potentially, to the onset of seizures. For the prematurely born baby there is not only is this immediate loss of protective inhibition but a prolonged loss of the growth-promoting milieu that neurosteroids provide in utero.

The physiological importance of allopregnanolone for the brain immediately before birth is shown by the fact that inhibition of its synthesis is followed by greater spontaneous activity suggesting fetal arousal (Nicol et al., 2001), and by an increased incidence of isoelectric and spiking EEG activity following brief in utero asphyxia (Yawno et al., 2011). These effects are reduced by treatment with the 
synthetic pregnane analog alfaxalone (Yawno et al., 2011). Furthermore, the inhibition of allopregnanolone synthesis markedly increased asphyxia-induced cell death within the cerebellum and hippocampus (Yawno et al., 2007), injuries also diminished by administration of alfaxalone (Yawno et al., 2009).

Late gestation fetal hypoxia in ovine models (induced by occluding umbilical blood flow for $10 \mathrm{~min}$ ) leads to electrographic seizures and increased cell death in the hippocampus, basal ganglia and cerebellum (Castillo-Melendez et al., 2004; Yawno et al., 2007), and severe brainstem injury (George et al., 2004). Prolonged seizures increase metabolic demand throughout the brain, increasing global, and local (seizure-associated) cerebral blood flow, and perhaps directing perfusion away from injured brain regions, and thus limiting the supply of glucose and oxygen necessary to sustain endogenous protective and repair mechanisms in damaged organs. Furthermore, prolonged seizures increase production of diffusible neurotoxic molecules (e.g., inflammatory cytokines, glutamate, lactate, glycerol, reactive oxygen species), which can lead to ischemic cell damage (Gunn and Bennet, 2009).

It is worth mentioning that the 21-hydroxylated by-product of allopregnanolone, tetrahydrodeoxycorticosterone (THDOC), is an endogenous inhibitory neurosteroid with similar actions to those of allopregnanolone (Reddy, 2010), and there are few synthetic analog of allopregnanolone that have therapeutic potential. Alfaxalone is an anticonvulsant and neuroprotective against excitotoxic brain injury (Mellon, 2007; Hirst et al., 2014), however, it is not the ideal neurosteroid replacement therapy for neonates because of respiratory depression and apnea associated with its use (Mellon, 2007). Allopregnanolone itself is also not ideal for at least two reasons. Firstly, it has a short half-life in vivo, and has little or no bioavailability when given orally. Secondly, it can undergo isoenzyme-driven back conversion to produce active intermediates such as dihydroprogesterone sulfate and pregnenolone sulfate, both of which are negative modulators of the $\mathrm{GABA}^{\mathrm{A}}$ receptor, and thus, potentially, have pro-convulsant effects (Reddy, 2003).

\section{GANAXOLONE AS A NOVEL NEUROSTEROID-BASED ANTI-SEIZURE DRUG}

Ganaxolone is a synthetic $3 \beta$-methyl by-product of allopregnanolone (Bialer et al., 2010), which, like endogenous neurosteroids, modulates the activity of GABAergic interneurons via the benzodiazepine-binding site on $\mathrm{GABA}^{\mathrm{A}}$ receptors. Unlike allopregnanolone, ganaxolone does not undergo back-conversion due to the $3 \beta$-methyl substituent in its chemical structure (Turkmen et al., 2011), thus avoiding the side effects, biotransformation and tolerance associated with allopregnanolone, and alfaxolone. In humans, ganaxolone can be given orally and sufficient blood levels can be maintained in human subjects with two- or three-times daily dosing (Monaghan et al., 1997). Furthermore, while allopregnanolone is readily oxidized at the $3 \alpha$ position resulting in accumulation of 3 keto metabolites that are mostly inactive at neuronal membrane receptor sites, by contrast, the methylation of ganaxolone at the $3 \beta$ position ( $3 \alpha$-hydroxy-3 $\beta$-methyl-5 $\alpha$-pregnan-20-one) prevents rapid metabolism and thereby provides for greater bioavailability (Lyden et al., 2000).

\section{Preclinical Studies}

Ganaxolone is the only neurosteroid evaluated so far for the treatment of epilepsy in humans (Nohria and Giller, 2007). It has shown to have neuroprotective properties in adult rodent seizure models. In chronically treated rats, ganaxolone tachyphylaxis does not develop (Reddy and Rogawski, 2000). A study in amygdala-kindled mice showed that suppression of behavioral and electrographic seizures was achieved with a single low dose of $6.6 \mathrm{mg} / \mathrm{kg}$ (Reddy and Rogawski, 2010). In mice, ganaxolone has also shown to be a more efficient anti-convulsant agent compared to two regular anticonvulsants, diazepam and valproate (Gasior et al., 2000). It effectively prevents the development of clonic seizures and development of sensitisation to the convulsive (tonic and clonic) and lethal effects of pentylenetetrazol; and chronic (over 5 days) pre-treatment was more efficacious than acute (one daily dose) (Gasior et al., 2000). Similarly, ganaxolone has a better anticonvulsant index than ethosuxamine, and valproate in generalized absence and partial seizures (Carter et al., 1997).

So far, there are only few studies that have examined the efficacy of ganaxolone on seizure management in the developing and immature brain. Liptáková and colleagues found that ganaxolone has antiepileptic effects against chemically induced seizures amongst postnatal rat pups, aged 9, 15, 30, and 60 days (Liptakova et al., 2000). Ganaxolone is also effective in reducing the development of infantile spasm at postnatal day 15 (Yum et al., 2014). Pharmacokinetic studies in mice, rats, rabbits, and dogs show that ganaxolone has a broad steady-state volume of distribution indicating that it distributes extensively into tissues, including the brain (Ram et al., 2001), and unlike other neurotoxic anticonvulsants, ganaxolone has shown to suppress seizures without compromising brain development and motor function in rats (Mares and Stehlikova, 2010). Preand postnatal developmental studies in mice, rats, and dogs show that ganaxolone does not alter fetal viability, or growth, and development from birth to weaning, and no teratogenic or genotoxic effects have been noted. Similarly, ganaxolone treatment (orally) to conscious dogs at a dose of $10 \mathrm{mg} / \mathrm{kg}$ did not alter their blood pressure or heart rate.

\section{Clinical Safety and Efficacy Studies}

Ganaxolone was given to a large cohort $(>900)$ of subjects in doses up to $1,875 \mathrm{mg} /$ day in adults and up to $54 \mathrm{mg} / \mathrm{kg} /$ day in children in Phase 1 and Phase 2 studies and clinical trials for epilepsy (Table 1). Single oral doses of 50-1,600 $\mathrm{mg}$ in healthy subjects resulted in plasma concentrations of $14-460 \mathrm{ng} / \mathrm{ml}$ (Bialer et al., 2013). Pediatric trials to date have focused on adults and children with refractory seizures (patients who continue to have seizures despite taking multiple anticonvulsant drugs). An open-label, add-on trial in 16 pediatric patients aged 6 months to 7 years with infantile spasms and continuing seizures found it was well tolerated with a good pharmacokinetic profile. Spasm frequency was reduced by at least $50 \%$ in $33 \%$ of these subjects, 
TABLE 1 | Clinical trial in which Ganaxolone is used to treat epilepsy in children and adults.

\begin{tabular}{|c|c|c|c|c|c|c|}
\hline & Study title & Main objective & Country & Condition & Current status & Trial identifier \\
\hline 1 & $\begin{array}{l}\text { A Two-year Open-label Extension } \\
\text { Study of Ganaxolone in Patients With } \\
\text { Drug-resistant Partial-onset Seizures }\end{array}$ & $\begin{array}{l}\text { Two-year open-label extension study of } \\
\text { ganaxolone as add-on therapy in adult } \\
\text { patients with drug-resistant partial-onset } \\
\text { seizures }\end{array}$ & USA & $\begin{array}{l}\text { Drug Resistant Partial } \\
\text { Onset Seizure. } \\
\text { Age: } 18 \text { years and } \\
\text { older. Sex: males and } \\
\text { females }\end{array}$ & $\begin{array}{l}\text { Terminated. } \\
\text { 2015-2017 }\end{array}$ & NCT02519439 \\
\hline 2 & $\begin{array}{l}\text { Phase } 3 \text { Study of Adjunctive } \\
\text { Ganaxolone in Adults With } \\
\text { Drug-resistant Partial Onset Seizures } \\
\text { and Open-label Extension }\end{array}$ & $\begin{array}{l}\text { To determine the efficacy and safety of } \\
\text { ganaxolone as adjunctive therapy for } \\
\text { adults with drug-resistant partial-onset } \\
\text { seizures followed by long-term open-label } \\
\text { treatment }\end{array}$ & USA & $\begin{array}{l}\text { Drug Resistant Partial } \\
\text { Onset Seizure. } \\
\text { Age: } 18 \text { years and } \\
\text { older. Sex: males and } \\
\text { females }\end{array}$ & $\begin{array}{l}\text { Completed. } \\
2015-2017\end{array}$ & NCT01963208 \\
\hline 3 & $\begin{array}{l}\text { A Randomized, Controlled Trial of } \\
\text { Ganaxolone in Adult Uncontrolled } \\
\text { Partial-Onset Seizures }\end{array}$ & $\begin{array}{l}\text { To evaluate the effectiveness and safety of } \\
\text { ganaxolone on partial seizure frequency in } \\
\text { adults with epilepsy taking a maximum of } \\
3 \text { antiepileptic medications. The study will } \\
\text { also evaluate the effectiveness of } \\
\text { ganaxolone in females with catamenial } \\
\text { epilepsy }\end{array}$ & USA & $\begin{array}{l}\text { Partial Epilepsy; } \\
\text { Catamenial Epilepsy. } \\
\text { Age: 18-69 years. } \\
\text { Sex: males and females }\end{array}$ & $\begin{array}{l}\text { Completed. } \\
\text { 2007-2009 }\end{array}$ & NCT00465517 \\
\hline 4 & $\begin{array}{l}\text { A Treatment Use Protocol for } \\
\text { Subjects Continuing on From the } \\
\text { Open-label Extension } 0601 \text { (0602) }\end{array}$ & $\begin{array}{l}\text { To provide ganaxolone to those patients } \\
\text { deriving significant benefit from current } \\
\text { treatment in protocol 1042-0601 }\end{array}$ & USA & $\begin{array}{l}\text { Epilepsy, Complex } \\
\text { Partial. } \\
\text { Age: } 18-55 \text { years. } \\
\text { Sex: males and females }\end{array}$ & $\begin{array}{l}\text { Completed. } \\
\text { 2009-2013 }\end{array}$ & NCT01002820 \\
\hline 5 & $\begin{array}{l}\text { A Multicenter, Open-Label } \\
\text { Proof-of-Concept Trial of Ganaxolone } \\
\text { in Children With PCDH19 Female } \\
\text { Pediatric Epilepsy }\end{array}$ & $\begin{array}{l}\text { To evaluate ganaxolone as adjunctive } \\
\text { therapy for uncontrolled seizures in female } \\
\text { children with PCDH19 mutations. After } \\
\text { establishing baseline seizure frequency, } \\
\text { qualifying subjects will enter the study and } \\
\text { be treated with open-label ganaxolone for } \\
\text { up to } 6 \text { months }\end{array}$ & USA & $\begin{array}{l}\text { Epilepsy. } \\
\text { Age: } 2-10 \text { years. } \\
\text { Sex: females. }\end{array}$ & $\begin{array}{l}\text { Currently } \\
\text { recruiting. } 2015\end{array}$ & NCT02358538 \\
\hline 6 & $\begin{array}{l}\text { Open-label Extension to Protocol } \\
1042-0600\end{array}$ & $\begin{array}{l}\text { To evaluate efficacy and safety of } \\
\text { ganaxolone treatment in adults with partial } \\
\text { onset epilepsy with or without secondary } \\
\text { generalizations }\end{array}$ & USA & $\begin{array}{l}\text { Epilepsies, Partial. } \\
\text { Age: 18-69 years. } \\
\text { Sex: males and females }\end{array}$ & $\begin{array}{l}\text { Completed. } \\
\text { 2007-2013 }\end{array}$ & NCT00512317 \\
\hline 7 & $\begin{array}{l}\text { A Randomized, Controlled Trial of } \\
\text { Ganaxolone in Patients With Infantile } \\
\text { Spasms }\end{array}$ & $\begin{array}{l}\text { To evaluate the safety, tolerability, and } \\
\text { antiepileptic activity of ganaxolone in } \\
\text { treatment of patients with infantile spasms }\end{array}$ & USA & $\begin{array}{l}\text { Infantile Spasms. } \\
\text { Age: } 4-24 \text { months. } \\
\text { Sex: males and females }\end{array}$ & $\begin{array}{l}\text { Completed. } \\
\text { 2007-2009 }\end{array}$ & NCT00441896 \\
\hline
\end{tabular}

Information obtained from ClinicalTrials.gov. May 2017.

with an additional 33\% experiencing some improvement, and one patient achieved seizure freedom (Kerrigan et al., 2000). A further open-label, non-randomized, dose-escalation add-on trial was conducted in 20 highly resistance pediatric and adolescent patients, aged 5-15 years. After 8 weeks of treatment, $47 \%$ had a substantial or moderate decrease in seizure frequency (Pieribone et al., 2007). Although these studies utilized small numbers of patients, they provide evidence that ganaxolone reduces seizures with acceptable tolerance, and safety profile even in those refractory to other therapy.

It is important to note that the histopathology of the hypoxic brain with a history of epilepsy varies from signs of gliosis and neuronal cell loss to impaired cellular maturation processes, some of which is regulated by microRNAs. In this review, we have not discussed the role of microRNAs in epilepsy. However, Dogini et al. (2013) and Jimenez-Mateos and Henshall (2013) have recently published an extensive review on the role of microRNAs in epilepsy, where the expression of microRNAs is largely dysregulated during neurogenesis, which is a major reason for drug resistance in epilepsy. Next generation sequencing has been instrumental in identifying pediatric patients with early onset severe epilepsy and any associated progressive brain injury (Mei et al., 2017). Long-term exposure of adult cultured cells to ganaxolone does not alter $\mathrm{GABA}^{\mathrm{A}}$ receptor sensitivity, although it does alter $\mathrm{GABA}^{\mathrm{A}}$ receptor composition by reducing the mRNA of $\alpha 1$ and $\gamma 2$ subunits, and increasing $\alpha 4$ subunit mRNAs (Mascia et al., 2002). The consequences of these alterations of receptor subunit composition have not been investigated, but are likely to be significant. Further expression-profiling studies may reveal changes to brain miRNA levels following ganaxolone treatment in appropriate animal models of preterm or term seizure-induced brain injury, which will be of value to clinical studies.

\section{THE GABA ${ }^{A}$ RECEPTOR SWITCH}

The GABAergic signaling is unique in that its action is dependent on the intracellular concentrations of chloride $\left[\mathrm{Cl}^{-}\right]$, which can lead to either depolarization and excitation or 
hyperpolarization, and inhibition. The important regulators of $\mathrm{Cl}^{-}$transport are NKCC1 and NKCC2 that respectively import and export $\mathrm{Cl}^{-}$. In adults, the interaction of neurosteroids such as ganaxolone with $\mathrm{GABA}^{\mathrm{A}}$ receptors normally increases conductance of the chloride channel causing hyperpolarization, and inhibition of excitability. However, the role of $\mathrm{GABA}^{\mathrm{A}}$ receptors in the regulation of excitability is dependent on neuronal maturation, synaptic plasticity, and pathological conditions, and there are notable species differences. For example, in rodent, during embryonic/fetal life and until at least postnatal life 9, immature neurons express the $\mathrm{Na}^{+}$ KCC1 (NKCC1) transporter, correlating with high internal $\left[\mathrm{Cl}^{-}\right]$in these neurons. On maturation, there is a decrease in NKCC1 transporter expression and an increase in expression of the $\mathrm{K}^{+} / \mathrm{Cl}^{-}$(KCC2) transporter. These developmental changes coincide with a decrease in $\left[\mathrm{Cl}^{-}\right]$, and $\mathrm{GABA}^{\mathrm{A}}$ receptor stimulation then tends to hyperpolarize the cell causing inhibition (Delpire, 2000). In human neonates (and in other precocial species), greater presence of mature neurons leads to the $\mathrm{GABA}^{\mathrm{A}}$ receptor becoming inhibitory, which is evident from at least 24-26 weeks (Ben-Ari et al., 2012), and in the latter part of gestation in other long gestation species. This indicates that the very premature infant may not be an ideal candidate for neurosteroid therapy, and it is therefore important to determine regulation of neuronal $\mathrm{Cl}^{-}$in the very premature infant, and if the switch in $\mathrm{GABA}^{\mathrm{A}}$ receptor function can be pharmacologically manipulated.

\section{THE CHALLENGE}

There is an opportunity to shift the paradigm of neonatal seizure management in changing both the timing of treatment

\section{REFERENCES}

Belelli, D., and Lambert, J. J. (2005). Neurosteroids: endogenous regulators of the GABA(A) receptor. Nat. Rev. Neurosci. 6, 565-575. doi: 10.1038/nrn1703

Ben-Ari, Y., Khalilov, I., Kahle, K. T., and Cherubini, E. (2012). The GABA excitatory/inhibitory shift in brain maturation and neurological disorders. Neuroscientist 18, 467-486. doi: 10.1177/10738584124 38697

Bialer, M., Johannessen, S. I., Levy, R. H., Perucca, E., Tomson, T., and White, H. S. (2010). Progress report on new antiepileptic drugs: a summary of the tenth Eilat Conference (EILAT X). Epilepsy Res. 92, 89-124. doi: 10.1016/j.eplepsyres.2010.09.001

Bialer, M., Johannessen, S. I., Levy, R. H., Perucca, E., Tomson, T., and White, H. S. (2013). Progress report on new antiepileptic drugs: the Eleventh Eilat Conference (EILAT XI). Epilepsy Res. 103, 2-30. doi: 10.1016/j.eplepsyres.2012.10.001

Bittigau, P., Sifringer, M., and Ikonomidou, C. (2003). Antiepileptic drugs and apoptosis in the developing brain. Ann. N Y Acad. Sci. 993, 103-114.

Bjorkman, S. T., Miller, S. M., Rose, S. E., Burke, C., and Colditz, P. B. (2010). Seizures are associated with brain injury severity in a neonatal model of hypoxia-ischemia. Neuroscience 166, 157-167. doi: 10.1016/j.neuroscience.2009.11.067

Boylan, G. B., Rennie, J. M., Chorley, G., Pressler, R. M., Fox, G. F., Farrer, K., et al. (2004). Second-line anticonvulsant treatment of neonatal seizures: a video-EEG monitoring study. Neurology 62, 486-488. doi: 10.1212/01.WNL.0000106944.59990.E6 and the agent used. Despite the acknowledged adverse side effects associated with phenobarbitone, it is still considered the initial drug of choice for the treatment of neonatal seizure, simply because options are limited. And because phenobarbitone-like drugs are known to have significant side effects, the reasonable caution in using them leads to delay in the treatment of neonatal seizures. We propose there are physiological reasons that synthetic pregnane steroids such as ganaxolone may be useful in suppressing neonatal seizures following hypoxic injury. Our studies with a relevant pre-clinical model (late gestation fetal sheep) have shown that endogenous neurosteroids that act through the $\mathrm{GABA}^{\mathrm{A}}$ receptor pathway are neuroprotective, and they also function as effective antiseizure agents. Therefore, further research into the anti-seizure properties of allopregnanolone analog with a $\mathrm{GABA}^{\mathrm{A}}$ receptor agonist actions is warranted, particularly if it can be shown they avoid the side effects and reduced efficacy associated with the current use of phenobarbitone. The capacity to provide seizure control and neuroprotection with a safe agent administered early following hypoxia will improve the outcomes for our sickest neonates.

\section{AUTHOR CONTRIBUTIONS}

TY, MF, and DW developed the idea. All authors collectively contributed to writing and drafting this mini review.

\section{ACKNOWLEDGMENTS}

The authors wish to acknowledge funding support from the Cerebral Palsy Alliance and the Victorian Government's Operational Infrastructure Support Program.

Boylan, G. B., Rennie, J. M., Pressler, R. M., Wilson, G., Morton, M., and Binnie, C. D. (2002). Phenobarbitone, neonatal seizures, and video-EEG. Arch. Dis. Child. Fetal Neonatal Ed. 86, F165-F170. doi: 10.1136/fn.86.3.F165

Brodie, M. J., and Kwan, P. (2012). Current position of phenobarbital in epilepsy and its future. Epilepsia 53(Suppl. 8), 40-46. doi: 10.1111/epi.12027

Bye, A. M., and Flanagan, D. (1995). Spatial and temporal characteristics of neonatal seizures. Epilepsia 36, 1009-1016. doi: 10.1111/j.1528-1157.1995.tb00960.x

Carter, R. B., Wood, P. L., Wieland, S., Hawkinson, J. E., Belelli, D., Lambert, J. J., et al. (1997). Characterization of the anticonvulsant properties of ganaxolone (CCD 1042; $3 \alpha$-hydroxy-3 $\beta$-methyl-5 $\alpha$-pregnan-20-one), a selective, highaffinity, steroid modulator of the $\gamma$-aminobutyric Acid $_{\mathrm{A}}$ receptor, J. Pharmacol. Exp. Ther. 280, 1284-1295.

Castillo-Melendez, M., Chow, J. A., and Walker, D. W. (2004). Lipid peroxidation, caspase-3 immunoreactivity, and pyknosis in late-gestation fetal sheep brain after umbilical cord occlusion. Pediatr. Res. 55, 864-871. doi: 10.1203/01.PDR.0000115679.86566.C4

Delpire, E. (2000). Cation-chloride cotransporters in neuronal communication. News Physiol. Sci. 15, 309-312.

Dessens, A. B., Cohen-Kettenis, P. T., Mellenbergh, G. J., Koppe, J. G., N. E., and van De Poll, Boer, K. (2000). Association of prenatal phenobarbital and phenytoin exposure with small head size at birth and with learning problems. Acta Paediatr. 89, 533-541.

Dogini, D. B., Avansini, S. H., Vieira, A. S., and Lopes-Cendes, I. (2013). MicroRNA regulation and dysregulation in epilepsy. Front. Cell. Neurosci. 7:172. doi: $10.3389 /$ fncel.2013.00172 
Dringen, R. (2005). Oxidative and antioxidative potential of brain microglial cells. Antioxid. Redox Signal. 7, 1223-1233. doi: 10.1089/ars.2005.7.1223

Evans, D. J., Levene, M. I., and Tsakmakis, M. (2007). Anticonvulsants for preventing mortality and morbidity in full term newborns with perinatal asphyxia. Cochrane Database Syst. Rev. 8:CD001240. doi: 10.1002/14651858.CD001240.pub2

Forcelli, P. A., Janssen, M. J., Vicini, S., and Gale, K. (2012). Neonatal exposure to antiepileptic drugs disrupts striatal synaptic development. Ann. Neurol. 72, 363-372. doi: 10.1002/ana.23600

Gasior, M., Ungard, J. T., Beekman, M., Carter, R. B., and Witkin, J. M. (2000). Acute and chronic effects of the synthetic neuroactive steroid, ganaxolone, against the convulsive and lethal effects of pentylenetetrazol in seizurekindled mice: comparison with diazepam and valproate. Neuropharmacology 39, 1184-1196. doi: 10.1016/S0028-3908(99)00190-2

George, S., Gunn, A. J., Westgate, J. A., Brabyn, C., Guan, J., and Bennet, L. (2004). Fetal heart rate variability and brain stem injury after asphyxia in preterm fetal sheep. Am. J. Physiol. Regul. Integr. Comp. Physiol. 287, R925-R933. doi: 10.1152/ajpregu.00263.2004

Glass, H. C. (2014). Neonatal seizures: advances in mechanisms and management. Clin. Perinatol. 41, 177-190. doi: 10.1016/j.clp.2013.10.004

Glass, H. C., and Wirrell, E. (2009). Controversies in neonatal seizure management. J. Child Neurol. 24, 591-599. doi: 10.1177/0883073808327832

Gunn, A. J., and Bennet, L. (2009). Fetal hypoxia insults and patterns of brain injury: insights from animal models. Clin. Perinatol. 36, 579-593. doi: 10.1016/j.clp.2009.06.007

Hirst, J. J., Kelleher, M. A., Walker, D. W., and Palliser, H. K. (2014). Neuroactive steroids in pregnancy: Key regulatory and protective roles in the foetal brain. J. Steroid Biochem. Mol. Biol. 139, 144-153. doi: 10.1016/j.jsbmb.2013.04.002

Holmes, G. L. (2009). The long-term effects of neonatal seizures. Clin. Perinatol. 36, 901-914. doi: 10.1016/j.clp.2009.07.012

Jimenez-Mateos, E. M., and Henshall, D. C. (2013). Epilepsy and microRNA. Neuroscience 238, 218-229. doi: 10.1016/j.neuroscience.2013.02.027

Johansson, I. M., Birzniece, V., Lindblad, C., Olsson, T., and Backstrom, T. (2002). Allopregnanolone inhibits learning in the Morris water maze. Brain Res. 934, 125-131. doi: 10.1016/S0006-8993(02)02414-9

Kanes, S. J., Colquhoun, H., Doherty, J., Raines, S., Hoffmann, E., Rubinow, D. R., et al. (2017). Open-label, proof-of-concept study of brexanolone in the treatment of severe postpartum depression. Hum. Psychopharmacol. 32:e2576. doi: 10.1002/hup.2576

Kerrigan, J. F., Shields, W. D., Nelson, T. Y., Bluestone, D. L., Dodson, W. E., Bourgeois, B. F., et al. (2000). Ganaxolone for treating intractable infantile spasms: a multicenter, open-label, add-on trial. Epilepsy Res. 42, 133-139. doi: 10.1016/S0920-1211(00)00170-4

Khanna, A., Walcott, B. P., and Kahle, K. T. (2013). Limitations of Current GABA Agonists in Neonatal seizures: toward GABA modulation via the targeting of neuronal Cl(-) transport. Front Neurol. 4:78. doi: 10.3389/fneur.2013.00078

Levene, M. (2002). The clinical conundrum of neonatal seizures. Arch. Dis. Child. Fetal Neonatal Ed. 86, F75-F77. doi: 10.1136/fn.86.2.F75

Liptakova, S., Velisek, L., Veliskova, J., and Moshe, S. L. (2000). Effect of ganaxolone on flurothyl seizures in developing rats. Epilepsia 41, 788-793. doi: 10.1111/j.1528-1157.2000.tb00244.x

Lyden, P., Shin, C., Jackson-Friedman, C., Hassid, S., Chong, A., and Macdonald, R. L. (2000). Effect of ganaxolone in a rodent model of cerebral hematoma, Stroke 31, 169-175. doi: 10.1161/01.STR.31.1.169

Mares, P., and Stehlikova, M. (2010). Anticonvulsant doses of ganaxolone do not compromise motor performance in immature rats. Neurosci. Lett. 469, 396-399. doi: 10.1016/j.neulet.2009.12.037

Mascia, M. P., Biggio, F., Mancuso, L., Cabras, S., Cocco, P. L., Gorini, G., et al. (2002). Changes in GABA(A) receptor gene expression induced by withdrawal of, but not by long-term exposure to, ganaxolone in cultured rat cerebellar granule cells. J. Pharmacol. Exp. Ther. 303, 1014-1020. doi: 10.1124 /jpet.102.040063

McBride, M. C., Laroia, N., and Guillet, R. (2000). Electrographic seizures in neonates correlate with poor neurodevelopmental outcome. Neurology 55, 506-513. doi: 10.1212/WNL.55.4.506

Mei, D., Parrini, E., Marini, C., and Guerrini, R. (2017). The impact of nextgeneration sequencing on the diagnosis and treatment of epilepsy in paediatric patients. Mol. Diagn. Ther. 21, 357-373. doi: 10.1007/s40291-017-0257-0
Mellon, S. H. (2007). Neurosteroid regulation of central nervous system development. Pharmacol. Ther. 116, 107-124. doi: 10.1016/j.pharmthera.2007.04.011

Monaghan, E., Navalta, L., Lee, D., Shum, L., and Ashbrook, D. W. (1997). Initial human experience with ganaxolone, a neuroactive steroid with antiepileptic activity. Epilepsia 38, 1026-1031. doi: 10.1111/j.1528-1157.1997.tb01486.x

Nguyen, P. N., Billiards, S. S., Walker, D. W., and Hirst, J. J. (2003). Changes in 5alpha-pregnane steroids and neurosteroidogenic enzyme expression in the perinatal sheep. Pediatr. Res. 53, 956-964. doi: 10.1203/01.PDR.0000064905.64688.10

Nicol, M. B., Hirst, J. J., and Walker, D. (1999). Effects of pregnanolone on behavioural parameters and the responses to $\operatorname{GABA}(\mathrm{A})$ receptor antagonists in the late gestation fetal sheep. Neuropharmacology 38, 49-63. doi: 10.1016/S0028-3908(98)00166-X

Nicol, M. B., Hirst, J. J., and Walker, D. W. (2001). Effect of finasteride on behavioural arousal and somatosensory evoked potentials in fetal sheep. Neurosci. Lett. 306, 13-16. doi: 10.1016/S0304-3940(01)01861-4

Nohria, V., and Giller, E. (2007). Ganaxolone. Neurotherapeutics 4, 102-105. doi: 10.1016/j.nurt.2006.11.003

Painter, M. J., Scher, M. S., Stein, A. D., Armatti, S., Wang, Z., Gardiner, J. C., et al. (1999). Phenobarbital compared with phenytoin for the treatment of neonatal seizures. New Eng. J. Med. 341, 485-489. doi: 10.1056/NEJM199908123410704

Pieribone, V. A., Tsai, J., Rey, E., Soufflet, C., Shaw, K., Giller, E., et al. (2007). Clinical evaluation of ganaxolone in pediatric and adolescent patients with refractory epilepsy. Epilepsia 48, 1870-1874. doi: 10.1111/j.1528-1167.2007.01182.x

Ram, K., Lam, G. N., and Chien, B. (2001). A HPLC-tandem mass spectrometric method for the determination of pharmacokinetics of ganaxolone in rat, monkey, dog and human plasma. J. Chromatogr. B Biomed. Sci. Appl. 751, 49-59. doi: 10.1016/S0378-4347(00)00447-3

Reddy, D. S. (2003). Pharmacology of endogenous neuroactive steroids. Crit. Rev. Neurobiol. 15, 197-234. doi: 10.1615/CritRevNeurobiol.v15.i34.20

Reddy, D. S. (2010). Neurosteroids: endogenous role in the human brain and therapeutic potentials. Prog. Brain Res. 186, 113-137. doi: 10.1016/B978-0-444-53630-3.00008-7

Reddy, D. S., and Rogawski, M. A. (2000). Chronic treatment with the neuroactive steroid ganaxolone in the rat induces anticonvulsant tolerance to diazepam but not to itself. J. Pharmacol. Exp. Ther. 295, 1241-1248.

Reddy, D. S., and Rogawski, M. A. (2010). Ganaxolone suppression of behavioral and electrographic seizures in the mouse amygdala model. Epilepsy Res. 89, 254-260. doi: 10.1016/j.eplepsyres.2010. 01.009

Reddy, D. S., and Rogawski, M. A. (2012). "Neurosteroids - endogenous regulators of seizure susceptibility and role in the treatment of epilepsy," in Jasper's Basic Mechanisms of the Epilepsies, 4th Edn., eds J. L. Noebels, M. Avoli, M. A. Rogawski, R. W. Olsen, and A. V. Delgado-Escueta (Bethesda, MD: National Center for Biotechnology Information).

Rennie, J., and Boylan, G. (2007). Treatment of neonatal seizures. Arch. Dis. Childhood. Fetal Neonatal Ed. 92, F148-F150. doi: 10.1136/adc.2004.068551

Srinivasakumar, P., Zempel, J., Trivedi, S., Wallendorf, M., Rao, R. Smith, B., et al. (2015). Treating EEG seizures in hypoxic ischemic encephalopathy: a randomized controlled trial. Pediatrics 136, e1302-1309. doi: 10.1542/peds.2014-3777

Turkmen, S., Backstrom, T., Wahlstrom, G., Andreen, L., and Johansson, I. M. (2011). Tolerance to allopregnanolone with focus on the GABA-A receptor. $\mathrm{Br}$. J. Pharmacol. 162, 311-327. doi: 10.1111/j.1476-5381.2010.01059.x

Wasterlain, C. G., Gloss, D. S., Niquet, J., and Wasterlain, A. S. (2013). Epileptogenesis in the developing brain. Handb. Clin. Neurol. 111, 427-439. doi: 10.1016/B978-0-444-52891-9.00046-4

World Health Organisation (2011). Guidline on Neonatal Seizures. Available online at: http://apps.who.int/mental_health/publications/guidelines_neonatal_ seizures/en/

Yawno, T., Hirst, J. J., Castillo-Melendez, M., and Walker, D. W. (2009). Role of neurosteroids in regulating cell death and proliferation in the late gestation fetal brain. Neuroscience 163, 838-847. doi: 10.1016/j.neuroscience.2009.07.009

Yawno, T., Yan, E. B., Hirst, J. J., and Walker, D. W. (2011). Neuroactive steroids induce changes in fetal sheep behavior during normoxic and asphyxic states. Stress 14, 13-22. doi: 10.3109/10253890.2010.504789 
Yawno, T., Yan, E. B., Walker, D. W., and Hirst, J. J. (2007). Inhibition of neurosteroid synthesis increases asphyxia-induced brain injury in the late gestation fetal sheep. Neuroscience 146, 1726-1733. doi: 10.1016/j.neuroscience.2007.03.023

Young, L., Berg, M., and Soll, R. (2016). Prophylactic barbiturate use for the prevention of morbidity and mortality following perinatal asphyxia. Cochrane Database Syst. Rev. 5:CD001240. doi: 10.1002/14651858.CD001240.pub3

Yum, M. S., Lee, M., Ko, T. S., and Velisek, L. (2014). A potential effect of ganaxolone in an animal model of infantile spasms. Epilepsy Res. 108, 1492-1500. doi: 10.1016/j.eplepsyres.2014. 08.015
Conflict of Interest Statement: The authors declare that the research was conducted in the absence of any commercial or financial relationships that could be construed as a potential conflict of interest.

Copyright (๑) 2017 Yawno, Miller, Bennet, Wong, Hirst, Fahey and Walker. This is an open-access article distributed under the terms of the Creative Commons Attribution License (CC BY). The use, distribution or reproduction in other forums is permitted, provided the original author(s) or licensor are credited and that the original publication in this journal is cited, in accordance with accepted academic practice. No use, distribution or reproduction is permitted which does not comply with these terms. 